\title{
Teachers' perspectives toward the implementation of bilingual immersion program in Indonesian private schools
}

\author{
1Haris Ma'ruf*, 1Huyi Intan Sari \\ English Education Department, Faculty of Language and Communication Science \\ Universitas Islam Sultan Agung, Indonesia
}

*Corresponding Author

haris@unissula.ac.id

\begin{abstract}
This research was to find out teachers' perspectives of the immersion program. For the mathematics, science and social subject teachers, it could ascertain how teachers cope with new challenges because using English to teach was a professional development experience and also could establish baseline approaches for implementing the immersion program. This study provided a picture of non-English teachers' perception on implementing an immersion program at SMA Islam Sultan Agung 1 Semarang. The data was obtained from questionnaires and observation. The main challenge facing non-English language teachers was teaching and learning Mathematics, Sciences (Physics, Chemist, and Biology) and Social Subjects (Sociology, Economics, and Geography) in English. The study also showed that there were specific situations when teachers felt frustrated teaching an immersion class. This frustration always relates to lack of English language proficiency. In conclusion, this study shows the lack of English language proficiency is the main challenge faced by non-English language teachers and students in immersion classes at SMA Islam Sultan Agung 1 Semarang.
\end{abstract}

Keywords: Teachers' perspective; bilingual school, Immersion Program

Received:

6 August 2019
Revised:

27 January 2020
Accepted:

27 February 2020
Published:

29 February 2020

\section{INTRODUCTION}

The Constitutional Court (MK) made a historic decision to grant a judicial review of Article 50, paragraph 3 of Law No. 20/2003 on the national education system, which was the legal basis for the establishment of the international-standard school pilot project (RSBI) by the government. The review was submitted by the Coalition for Anti-Commercialization of Education. With this decision, more than 1,300 RSBIs across the country, by law, must be dissolved because they no longer have a legal basis. 
This decision has been welcomed by many, especially those who have criticized the existence of the RSBIs. They agreed that the RSBI was not in line with the spirit of the 1945 Constitution and has led to discrimination and social segregation in education. The Court also considered that the use of English as the medium of instruction in the RSBIs could potentially erode national identity.

On the other hand, although RSBI has been dismissed by the Constitution Court, Bilingual education still becomes favorite trend. Bilingual education has recently been a prestige for a number of educational institutions in Indonesia, especially the pre-university ones. Bilingual is defined as being "able to speak two languages equally well because you have used them since you were very young" (Oxford, 2002), which broadens it meanings to include also the written language in bilingual education or communities. Bilingual education refers to "the use of a second or foreign language in school for the teaching of content subjects" (Richards et. al., 1992).

Since 2009, SMA Islam Sultan Agung 1 Semarang, has implemented Bilingual Immersion Program. They chose to open the program in order to support the achievement of national educational program and to implement vision and mission of the school. They are still implementing bilingual immersion program nowadays.

Teachers, parents and the school community have a crucial role to play in ensuring the success of immersion education (Amaral 2001; Caron-Caldas $\&$ Caldas, 2000). Studies have been undertaken to find out teachers', parents' and students' attitudes toward bilingual education (Bridge, 2007; Combs, Evans, Fletcher, Jiménez \& Parra, 2000; Craig, 1996; de Jong, 2006; GarcíaNevarez, Stafford \& Arias, 2005; Oladejo, 2006).

Generally, however, teachers and students do find that implementing immersion programs is challenging. One of the challenges is about the use of target language because the goal of bilingual in teaching is using target language in every teaching material. According to Marsakawati (marsakawati: 2017), the use of target language is strongly recommended to be used. It is due to the belief that in order to develop students' target language proficiency, the teachers must expose the students with significant amount of target language input.

Among the many challenges facing the education programs in SMA Islam Sultan Agung 1 Semarang, and immersion programs in particular, more consideration needs to be paid to the views of non-content specialists. Many teachers tend to be neglected by language-focused uses. Therefore, this study aimed to find out teachers' perspectives on the stages of implementing an immersion program in SMA Islam Sultan Agung 1 Semarang.

\section{Research Questions}

What are teachers' perspectives towards the process of implementing an immersion program of SMA Islam Sultan Agung 1 Semarang? Specific 
questions were investigated; namely, what are the difficulties faced by teachers in implementing this program, and how do they cope with those problems?

\section{Research Objectives}

The objective of this research is to find out teachers' perspectives towards the process of implementing an immersion program of SMA Islam Sultan Agung 1 Semarang and ascertain how teachers cope with new challenges because using English to teach may be a professional development experience. This also can establish baseline approaches for implementing the immersion program.

\section{METHOD}

This research was a quantitative and descriptive research since it is a study that is designed to obtain information concerning the current status of phenomena. In addition, this is conducted to seek information to assist in decision making and not to test hypotheses (Ary et al, 1979, 295).

According to Gay $(1990,189)$ a descriptive study determines and report the way things are. Here, I described the use of English in the teaching of Mathematics, Sciences (Physics, Chemist, and Biology) and Social Subjects (Sociology, Economics, and Geography) in Immersion classes in SMA Islam Sultan Agung 1 Semarang.

This study conducted in SMA Islam Sultan Agung 1 Semarang which is located at J1. Mataram 657, Semarang, Central Java. The school was chosen as the setting of the study based on consideration that the school was chosen regarding the fact that it is still implementing Bilingual Immersion Program.

This research method provides details about the participants of the study and the instrument used and concludes with a description of data collection and data analysis procedures.

\section{Participants}

One of the most important things in conducting an observation is participant. The participants for the observation were the teachers who teach the immersion classes. The teachers are from any subject including mathematics, physics, chemistry, geography, sociology, and economics.

\section{Instruments}

Two instruments were used to gather data. First, teachers taught in the immersion class were observed. Second, a teachers' questionnaire collected information on the background of the immersion class teachers. The survey questioned teachers about the challenges they faced in implementing the immersion program and how they dealt with these challenges.

They were also asked about their perceptions as teachers implementing an immersion program at their school. The questionnaire was a paper-based survey; in other words, the survey was given directly to teachers. This questionnaire comprised twenty-five questions covering the teachers' perspectives about implementing the immersion program. 


\section{Procedure}

The Principal of the school was contacted to explain the purpose of this research and to obtain a permit to conduct the study at that school. After obtaining the permit, observation and questionnaire were done and given to the teachers who taught in the immersion program.

\section{Analysis}

Quantitative and descriptive methods were used in this study. First, the results of questionnaire were calculated by using MS Excel. Then, the calculation was being interpreted by describing the result one by one. The final result of questionnaire was in descriptive form.

\section{RESULTS AND DISCUSSION}

The findings of observation included curriculum, teaching process, the media and evaluation system. The findings of the observation would be discussed as follows:

\section{Curriculum}

Curriculum is a set of subject and education program given by a particular education caretaker institution which consists of course program giving to course participant in a certain time of education level. According to the Laws of National Education System Number 20 Year 2003, curriculum is a set of planning and arrangement about the objectives, content and material used as a guideline in holding teaching and learning processes to achieve certain objective. In this case, SMA Islam Sultan Agung 1 used School-Based Curriculum. Here, I would like to describe the findings of curriculum based on its elements:

\section{Syllabus}

Since SMA Islam Sultan Agung 1 had implemented immersion program, the syllabus should be written in English. It means that it was not only English subject that used English but also other subjects including mathematics, physics, chemistry, sociology, geography and economics. In fact, only sociology was found using English in its syllabus.

\section{Lesson plan}

As the same as syllabus, lesson plan should also be written in English. Teachers should write the lesson plans before they conducted teaching and learning processes. But the result of questionnaire showed that only a few teachers constructed lesson plan before they taught. Only mathematics and sociology teachers who constructed lesson plan before the teaching and learning processes in classroom.

\section{Teaching materials}

In SMA Islam Sultan Agung 1, the teachers have been provided a book as the teaching materials by the school. The books were written in bilingual. And in this case, the books were qualified to be the teaching materials. According to 
the questionnaire result, a few teachers gave additional materials to the students. They made the materials by themselves but sometimes they took from other sources.

\section{Teaching and learning process}

Most of the teachers observed were rarely and even never used English in their classes. They also stated that they used English only at the beginning and at the end of classes. A biology and physics teachers said that they used English at the beginning of the class and used it during the class when they want to ask students to do something, such as opening the book and doing the exercises. The economics teacher said that she never used English in her teaching and learning process.

One of the teachers, chemist teacher, used his English fully because he knew that he will be observed. On the other hand, he usually did not use his English when teaching his students. He used English, like most of the teachers in immersion program, at the beginning and at the end of class.

Science and mathematics teachers mentioned that it was difficult for them to explain terms of Science and Mathematics in English. Moreover, they argued that even using Indonesian sometimes students find difficulties to understand the subject. Therefore, teachers prefer to use Indonesian than English.

The economics teacher explained that she is not able to use English due to lack of vocabulary. Moreover, she stated that the hand books for the subject still use Indonesian. Thus, she prefers using Indonesian than English. From the data above it is clearly that Indonesian language is still favored by the teachers of immersion program classes.

During the teaching and learning process teachers sometimes encounter situations where they become frustrated when teaching in English. When they were asked to list the situation that they feel frustrated, teachers mention some cases. In this regard most of the teachers reported that they feel frustrated when they have to explain something in English but they do not know how to do this.

\section{Teaching Media}

Being a teacher in this program requires the ability to use appropriate technology such as computers and the internet as teaching aid. Biology teacher reported that preparing media is very challenging. He always tries to create teaching media such as PowerPoint presentation to support teaching process, even though he found difficulties dealing with the use of computer technology and the school facilities.

For the facilities, text books and the use of media, teachers try to minimize them by being creative. For example, in relation with lack of text books, some teachers try to download it from the internet. Even they said that it does not fulfill their expectation to have English text books.

\section{Evaluation System}

Evaluation was given to the students in the form of essay and multiple choices. Almost all of the evaluation in every subject used Bahasa Indonesia. 
However, on the subject of biology, chemist, and mathematics, evaluation was given in Bahasa Indonesia and English.

\section{Discussion}

This study found that the teachers faced challenges in implementing the immersion program at their school. The main one related to language proficiency. Since the teachers are non-native English language speakers and do not have an appropriate educational background in the target language, the language problem seems to be the most common challenge to implementing a bilingual or immersion program (Met \& Lorenz, n.d., in Johnson \& Swain, 1997; Walker\& Tedick, 2000).

Teachers usually have to prepare appropriate lesson materials and presentations for their classes. In immersion programs, however, even though the teachers have already mastered the subjects they teach, they are not always able to teach the subject in English because they lack English language proficiency. This leads to teachers being frustrated when confusion over the English language arises in the class.

Teachers may worry about their fluency in English and problems with grammar and pronunciation may affect the students' capacity to understand the subject being taught. Consequently, there are teachers who rarely use English when teaching in immersion programs (Johnson, cited in Johnson \& Swain 1997).

Teachers' perspectives about implementing the immersion program teachers felt frustrated when they did not understand specific terms or the students' questions. Brisk (2006) points out some words in everyday situations will have a different meaning when used in the mathematics classroom. Such words include equal, rational, irrational, column and table. These different meanings will create problems for both teachers and students when they use such words in a scientific or mathematical context.

Even if they try to learn a word's meaning from a dictionary, they may not be able to find the appropriate meaning for the context in which it is being used in the classroom. (Johnson, n.d., in Johnson and Swain, 1997). When situations such as these arise, sometimes teachers have to switch from the target language into the first language, in this case from English into Indonesian, to clarify the meaning.

Lack of resources such as appropriate text books and teaching aids was also identified as a key challenge in implementing an immersion program. Immersion program teachers are required to use English textbooks.

\section{CONCLUSION}

Overall, this study provides a picture of non-English teachers' perception on implementing an immersion program at SMA Islam Sultan Agung 1 Semarang. The data was obtained from questionnaires and observation. The main challenge facing non-English language teachers was teaching and learning Mathematics, Sciences (Physics, Chemist, and Biology) and Social Subjects (Sociology, Economics, and Geography) in English. The study also showed that there were specific situations when teachers felt frustrated teaching an immersion class. This frustration always relates to lack of English language proficiency. In conclusion, this study shows the lack of English language 
proficiency is the main challenge faced by non-English language teachers in immersion classes at SMA Islam Sultan Agung 1 Semarang.

\section{ACKNOWLEDGMENT}

We would like to appreciate for the chance and the assistance coming from the Dean of Languages and Science Communication Faculty, Mr. Hartono, for the editors and reviewers of of this journal, moreover for the special gratitude to Mrs. Huyi Intan Sari as the Head of English Education Study Program for her supports.

\section{REFERENCES}

Ary, D., Razavieh, A., Jacobs, C.L. \& Sorensen C. 1979. Introduction to research in education. Wringley: Thomson Wadsworth.

Baradja, M.F. 1990. Kapita selekta pengajaran bahasa. Malang: Penerbit IKIP Malang.

Bogdan, R.C \& Biklen, S.K. 2003. Qualitative research for education: An introduction to theories and. methods (4th ed.). New York: Pearson Education group.Botswick, M (2001) English immersion in a Japanese school, in Christian, D, \& Genesee, F (2001) (Eds) Bilingual Education, USA, Teachers of English to Speakers of Other Languages, Inc.

Brondum, J. \& Stenson, S. 1998. Types of immersion education: An Introduction (on line). accessed on 11 May 2017.

Caldas, S. \& S. Caron-Caldas. 2000. The influence of family, school, and community on bilingual preference: Results from a Louisiana/Quebec case study. Journal of Applied Psycholinguistics 21(3). 365-381.

Genesee, F. (1987). Learning through two languages. (First ed.). Cambridge, Mass.: Newbury House Publishers. (Harper \& Row).

http://www.carla.umn.edu/immersion/main/topic3.html. accessed on 11 May 2017

http://tuj.academia.edu/MikeBostwick/Papers/644161/What_is_immersion, accessed on 11 May 2017

Johnson, R. K. \& Swain, M. (Eds) (1997). Immersion education: International perspectives, Cambridge: Cambridge University Press.

Marsakawati, N.P.E. (2017) Language choice in multilingual context: the use pf 11 in the hospitality english courses. Edulite, Journal of English Education, Literature, and Culture, 2(1), 263-272. DOI: http://dx.doi.org/10.30659/e.2.1.263-272

Oladejo, J. 2006. Parents' attitudes towards bilingual education policy in Taiwan. Bilingual Research Journal, 30 (1), 147-170. 
Ma'ruf, H., \& Sari, H.I. (2020). Extensive reading to improve students' writing skill of explanation text. EduLite: Journal of English Education, Literature, and Culture, 5 (1), 118-125.

DOI: http://dx.doi.org/10.30659/e.5.1.118-125

Snow, M. A. (1986). Innovative Second Language Education: Bilingual Immersion Programs (Report- Evaluative/Feasibility 142): UCLA. Center for Language Education and Research. 